\title{
HUBUNGAN SISTEM INFORMASI MANAJEMEN DENGAN KINERJA KARYAWAN BRI CABANG RANTAUPRAPAT
}

\author{
Zulkifli Musannip Efendi Siregar \\ Dosen Tetap Sekolah Tinggi Ilmu Ekonomi (STIE) Labuhanbatu
}

\begin{abstract}
ABSTRAK
Sistem informasi manajemen merupakan kumpulan-kumpulan dari sistem-sistem yang menyediakan informasi untuk mendukung manajemen. Sedangkan kinerja merupakan hasil kerja maupun secara kualitas maupun kuantitas yang dicapai oleh karyawan. Penelitiani ini bertujuan untuk mengetahui hubungan antara sistem informasi manajemen dengan kinerja pegawai. Hipotesis dalam penelitian ini yaitu ada hubungan yang kuat antara sistem informasi manajemen dengan kinerja karyawan BRI Cabang Rantauprapat. Metode yang digunakan dalam penelitian ini adalah dengan menggunakan metode analisis korelasi sederhana dengan dibantu program SPSS. Hasil penelitian menunjukkan adanya hubungan yang kuat antara system informasi manajemen dengan kinerja karyawan pada BRI Cabang Rantauprapat.
\end{abstract}

\section{Pendahuluan}

PT. BRI (Persero) Tbk merupakan salah satu bank tertua di Indonesia. BRI terbesar ke pelosok tanah air. Setiap perusahaan pasti menginginkan karyawannya memberikan kinerja yang baik dalam bekerja. Karyawan merupakan asset penting dalam bisnis, dan harus dikelola dengan baik. Banyak factor yang mendukung kebershasilan perusahaan dalam meningkatkan kinerja karyawan. Termasuk faktor internal maupun factor eksternal. Faktor internal dapat berupa motivasi, semangat, loyalitas karyawan itu sendiri. Sedangkan factor luar dapat berupa kepemimpinan, rekan kerja, suasana kerja, dan juga dukungan system informasi manajemen yang disediakan olehperusahaan. PT Bank Rakyat Indonesia (Persero) Tbk, telah mempublikasikan kinerja keuangan Tahun 2014. Menutup tahun 2014 ini, Bank BRI telah berhasil mencatatkan angka gemilang dalam industry perbankan, yaitu dengan membukukan Total Aset sebesar Rp. 778,02 Triliun tumbuh sebesar 28,34 \% jika dibandingkan tahun 2013, yang tercatat sebesar Rp.606,37 Triliun. Selain itu, dari hasil kegiatan operasional Bank BRI, baik pinjaman maupun jasa perbankan lainnya, Bank BRI berhasil mencatatkan perolehan laba bersih sebesar Rp.24,20 triliun (Bank Only) pada laporan Tahun 2014 atau meningkat sebesar 14,35\% (yoy) dibandingkan periode yang sama tahun 2013. Pertumbuhan laba bersih ini menghasilkan earning per share (EPS) sebesar Rp. 981,- per lembar saham lebih besar dari angka di periode yang sama tahun lalu sebesar Rp. 858,- per lembarsaham.

Keberhasilan PT Bank Rakyat Indonesia (Persero) Tbk pada tahun 2014 tidak terlepas dari pengelolaan sumber daya perusahaan dengan baik. Sumber daya dalam perusahaan tidak hanya menyangkut sumber daya manusia, material, dan juga financial. Informasi juga merupakan salah satu sumber daya yang sangat penting dalam bisnis. Perusahaan besar seperti BRI, haruslah mampu mengelola informasi dengan baik, baik untuk internal maupun eksternal. Hampir semua bidang kegiatan dalam suatu orgnisasi tidak akan terlepas dari informasi sebagai sarana penunjang kelancaran kegiatan kinerja pegawai yang telah ditetapkan sebelumnya didalam tubuh organisasi. 
Menurut Atkinson (1995) bahwa informasi yang dihasilkan dari sistem informasi dapat digunakan untuk mengukur kinerja ekonomi dari unit organisasi dalam perusahaan. Romney (1992), menyatakan bahwa manfaat utama dari informasi adalah mengurangi ketidakpastian, mendukung keputusan, dan medorong lebih baik dalam hal perencanaan dan penjadualan aktivitas kerja. David Kroenke (1999) menyatakan bahwa manajemen dalam menjalankan fungsi dan aktivitas bisnisnya yang meliputi Planning (Perencanaan), Organizing (Pengorganisasian), Actuating (Pengarahan), dan Controlling (Pengendalian), senantiasa memerlukan informasi untuk membuat keputusan.

Informasi dapat diibaratkan sebagai darah yang mengalir di dalam tubuh manusia, seperti halnya informasi di dalam sebuah perusahaan yang sangat penting untuk mendukung kelangsungan perkembangannya, sehingga terdapat alasan bahwa informasi sangat dibutuhkan bagi sebuah perusahaan. Akibat bila kurang mendapatkan informasi, dalam waktu tertentu perusahaan akan mengalami ketidakmampuan mengontrol sumber daya, sehingga dalam mengambil keputusan- keputusan strategis sangat terganggu, yang pada akhirnya akan mengalami kekalahan dalam bersaing dengan lingkungan pesaingnya. Disamping itu, sistem informasi yang dimiliki seringkali tidak dapat bekerja dengan baik.

Masalah utamanya adalah bahwa sistem informasi tersebut terlalu banyak informasi yang tidak bermanfaat atau berarti (sistem terlalu banyak data). Memahami konsep dasar informasi adalah sangat penting (vital) dalam mendesain sebuah sistem informasi yang efektif (effective business system). Menyiapkan langkah atau metode dalam menyediakan informasi yang berkualitas adalah tujuan dalam mendesain system baru.

Sebuah perusahaan mengadakan transaksi-transaksi yang harus diolah agar bisa menjalankan kegiatannya sehari-hari. Daftar gaji harus disiapkan, penjualan dan pembayaran atas perkiraan harus dibutuhkan: semua ini dan hal-hal lainnya adalah kegiatan pengolahan data dan harus dianggap bersifat pekerjaan juru tulis yang mengikuti suatu prosedur standar tertentu.

\section{Rumusan Masalah}

Rumusan masalah dalam penelitian ini adalah apakah terdapat hubungan system informasi manajemen dengan kinerja pegawai pada BRI rantauprapat.

\section{Tujuan Penelitian}

Tujuan penelitian ini adalah untuk mengetahui hubungan system informasi manajemen dengan kinerja pegawai pada BRI rantauprapat.

\section{Kajian Teori}

\section{Pengertian Sistem InformasiManajemen}

Sistem informasi manajemen merupakan penerapan sistem informasi didalam organisasi untuk mendukung informasi-informasi yang dibutuhkan oleh semua tingkatan manajemen. Definisi sistem informasi manajemen menurut pendapat Robert W. Holmes dalam Onong Uchjana Effendy dengan buku Sistem Informasi Manajemen (1989:112), bahwa: Sistem informasi Manajemen adalah suatu sistem yang dirancang untuk menyajikan informasi pilihan yang berorientasi kepada keputusan yang diperlukan oleh manajemen guna merencanakan, mengawasi, dan menilai aktivitas organisasi. Dirancangnya itu didalam kerangka kerja yang menitikberatkan pada perencanaan keuntungan, perencanaan penampilan, dan pengawasan pada semua tahap. 
Peneliti mengemukakan pendapat Azhar Susanto dalam buku Sistem Informasi Manajemen Konsep dan Pengembangannya (2002:68), yang mengemukakan pengertian Sistem Informasi Manajemen, yaitu Sistem Informasi Manajemen merupakan kumpulan dari sub-sub sistem yang saling berhubungan satu sama lain dan bekerja sama secara harmonis untuk mencapai satu tujuan yaitu mengolah data menjadi informasi yang diperlukan oleh manajemen dalam proses pengambilan keputusan saat melaksanakan fungsinya.

Pendapat lain tentang Sistem Informasi Manajemen yang ditulis oleh Jogianto Hartono dalam bukunya Pengenalan Komputer (2000:700), sebagai berikut Sistem Informasi Manajemen adalah kumpulan dari interaksi sistem-sistem informasi yang bertanggung jawab mengumpulkan dan mengolah data untuk menyediakan informasi yang berguna untuk semua tingkat manajemen didalam kegiatan perencanaan dan pengendalian.

Sesuai dengan makna istilahnya, Sistem Informasi Manajemen harus ditinjau dengan pendekatan sistem. Ini berarti bahwa manajemen itu sendiri dimana proses informasi berlangsung harus dilihatnya sebagai sistem, dalam hal ini sebagai total system. Dengan mengatakan manajemen sebagai total system, maka Sistem Informasi Manajemen merupakan salah satu sub sistem dari sekian banyak sub sistem yang tercakup oleh total system tersebut.

Pada dasarnya sistem informasi mempunyai tiga kegiatan utama yaitu: menerima data sebagai masukan, kemudian memprosesnya dengan melakukan perhitungan, penggabungan unsur-unsur data dan akhirnya dapat diperoleh informasi yang diperlukan sebagai keluaran. Prinsip tersebut berlaku baik bagi sistem informasi manual maupun sistem informasi modern dengan penggunaan perangkat komputer. Jadi pada dasarnya sebuah Sistem Informasi Manajemen adalah menerima dan memproses data untuk kemudian mengubahnya menjadi informasi yang berguna bagi para pengguna informasi dalam tingkatan manajemen.

\section{Indikator Sistem Informasi Manajemen}

Adapun indikator-indikator dari sistem informasi manajemen yang dikemukakan oleh Gordon B. Davis dalam buku yang berjudul Kerangka Dasar Sistem Informasi Manajemen Bagian I (1995:57), yaitu:

1. Informasi

Informasi merupakan hasil dari pengolahan data akan tetapi tidak semua hasil dari pengolahan tersebut bisa menjadi informasi, hasil pengolahan data yang tidak memberikan arti serta tidak bermanfaat bagi seseorang bukanlah merupakan informasi bagi orang tersebut.

2. Manusia sebagai pengolah informasi

Peranan manusia disini sangat besar yaitu untuk menciptakan informasi yang akurat, tepat waktu, relevan, dan lengkap. Baik buruknya informasi yang dihasilkan tergantung dari profesionalitas dari manusia itu sendiri.

3. Konsep sistem

Sistem adalah suatu bentuk kerjasama yang harmonis antara bagian/komponen/sub sistem yang saling berhubungan satu dengan bagian/komponen/sub sistem lainnya untuk mencapai suatu tujuan. Selain itu sistem tidaklah berdiri sendiri tetapi juga dipengaruhi oleh lingkungan, baik itu lingkungan intern maupun lingkungan ekstern.

4. Konsep organisasi dan manajemen

Organisasi tidak bisa lepas dari kegiatan manajemen dan begitu pula sebaliknya karena keduanya mempunyai hubungan yang begitu erat dan kuat.

5. Konsep pengambilan keputusan 
Pengambilan keputusan adalah tindakan pimpinan untuk memecahkan masalah yang dihadapinya dalam organisasi yang dipimpinnya dengan melalui pemilihan satu diantara alternatif-alternatif yang dimungkinkan.

6. Nilai informasi

Informasi dapat mengubah sebuah keputusan. Perubahan dalam nilai hasil akan menentukan informasi. Bahwa suatu informasi itu harus dapat menjadi ukuran yang tepat, yang nantinya dapat memberikan masukan bagi pimpinan dalam pengambilan keputusan.

\section{Pengertian Kinerja Pegawai}

Mangkunegara (2009:67), berpendapat bahwa kinerja (prestasi kerja) adalah "hasil kerja secara kualitas dan kuantitas yang dicapai oleh seorang pegawai dalam melaksanakan tugasnya sesuai dengan tanggung jawab yang diberikan kepadanya." Suwatno (2011:196) juga berpendapat bahwa "kinerja atau prestasi kerja merupakan hasil yang dicapai seseorang menurut ukuran yang berlaku, dalam kurun waktu tertentu, berkenaan dengan pekerjaan serta perilaku dan tindakanya. Sedangkan menurut Supriyanto dan Machfud (2010:132) kinerja diartikan "sebagai suatu hasil dari usaha seseorang yang dicapai dengan adanya kemampuan dan perbuatan dalam situasi tertentu." Dari beberapa pengertian di atas maka dapat disimpulkan bahwa kinerja karyawan merupakan hasil kerja seseorang baik secara kualitas maupun kuantitas berdasarkan tanggung jawab yang telah dibebankan kepada karyawan. Terdapat beberapa faktor yang mempengaruhi kinerja karyawan. Sebagaimana dikatakan oleh Mangkunegara (2009:67) bahwa faktor yang mempengaruhi pencapaian kinerja adalah faktor kemampuan (ability) dan faktor motivasi (motivation). Faktor kemampuan, secara psikologis kemampuan (abitity) pegawai terdiri dari kemampuan potensi (IQ) dan kemampuan realita (pendidikan). Oleh karena itu pegawai perlu ditempatkan pada pekerjaan yang sesuai dengan keahliannya. Faktor motivasi, motivasi terbentuk dari sikap (atitude) seorang pegawai dalam yang teararah untuk mencapai tujuan organisasi.

Dengan demikian kinerja adalah fungsi dari motivasi dan kemampuan atau $\mathrm{P}=\mathrm{f}(\mathrm{A} \mathrm{x}$ M) dimana $\mathrm{P}$ adalah performance, $\mathrm{M}$ adalah Motivasi, dan A adalah Ability. Sedangkan menurut Robbins (2007 : 241) perlu ditambahkan aspek kesempatan (Opportunity) kedalam persamaan di atas sehingga menjadi $\mathrm{P}=\mathrm{f}(\mathrm{A} \times \mathrm{M} \times \mathrm{O})$.

\section{Kerangka Konseptual}

Penerapan system informasi manajemen bertujuan mengelola sumber daya yang dimiliki perusahaan yaitu sumber daya informasi. Pengelolaan informasi yang baik akan memberikan kemudahan pegawai dalam bekerja. Sehingga, pada akhirnya penerapan system informasi manajemen dapat diharapkan meningkatkan kinerja pegawai dalam bekerja. Kinerja merupakan outcome.

Hubungan Sistem Informasi Manajemen dengan Kinerja Pegawai outcome yang dihasilkan dari fungsi suatu pekerjaan tertentu atau kegiatan selama satu periode waktu tertentu. Untuk mewujudkannya memerlukan dukungan dari berbagai faktor baik itu faktor internal maupun faktor eksternal. Keterkaitan sistem informasi manajemen dengan kinerja pegawai menyangkut berbagai aspek, keberadaan tiap level manajemen serta anggota organisasi dengan alat-alat yang telah tersedia menjadi suatu efektivitas pelaksanaan kegiatan yang menyentuh tugas dan fungsi organisasi.

Berdasarkan uraian di atas, dapat dibuat kerangka konseptual penelitian sebagai berikut 


\begin{tabular}{|c|c|}
\hline $\begin{array}{l}\text { Sistem Informasi Manajemen } \\
\text { Informasi } \\
\text { Manusia sebagai pengolah } \\
\text { informasi } \\
\text { Konsep pengambilankeputusan } \\
\text { Nilaiinformasi }\end{array}$ & $\begin{array}{l}\quad \text { Kinerja } \\
\text { - Kualitaskerja } \\
\text { - Kuantitakkerja } \\
\text { - Rasa Tanggung } \\
\text { Jawab }\end{array}$ \\
\hline
\end{tabular}

\section{Gambar 1. Kerangka Konseptual}

\section{Hipotesis}

Hipotesis dalam penelitian ini adalah terdapat hubungan yang kuat antara system informasi manajemen dengan kinerja pegawai Bank BRI Rantauprapat.

\section{Metode Penelitian}

PengumpulanData

Data merupakan sekumpulan nilai suatu fakta atau objek yang diyakini kebenarannya. Sumber data yang digunakan dalam penelitian ini adalah data primer yaitu dengan memberikan kuisiener kepada Pegawai BRIRantauprapat

\section{Analisis Korelasi}

Hipotesis dalam penelitian ini akan dianalisis secara kuantitatif dengan menggunakan “Analisis Korelasi”. Analisis korelasi yang dipakai adalah analisis Korelasi Pearson. Analisis ini dgunakan untuk menentukan apakah variabel independent mempunyai pengaruh yang signifikan terhadap variabel dependen. Analisis korelasi digunakan untuk mengetahui kuat lemahnya hubungan antara variabel independent dengan variabel dependen. Untuk memudahkan melakukan interpretasi mengenai kekuatan hubungan antara dua variabel penulis memberikan kriteria sebagai berikut (Sarwono:2006):

- 0 : Tidak ada korelasi antara duavariabel

- $>0-0,25$ : Korelasi sangatlemah

- >0,25-0,5: Korelasicukup

- >0,5-0,75: Korelasikuat

- >0,75 - 0,99: Korelasi sangatkuat

- 1: Korelasisempurna

\section{Pembahasan}

Sistem informasi manajemen memiliki peranan penting dalam memajukan perusahaan. Indikator system informasi manajemen yang digunakan dalam penelitian ini adalah informasi, manusia sebagai pengolah informasi, konsep pengambilan keputusan, nilai informasi. Sedangkan indicator kinerja dalam penelitian ini adalah kualitas kerja, kuantitas kerja dan rasa tanggung jawab. Berdasarkan analisis deskriptif menunjukkan bahwa system informasi manajemen dengan indicator nilai informasi memiliki rata-rata skor yang paling baik sebesar 4.5 dan disusul dengan manusia sebagai pengelola informasi. Untuk variable kinerja, indicator rasa tanggung jawab memiliki rata- rata skor paling tinggi. Secara umum penerapan system informasi manajemen dan kinerja karyawan pada PT. BRI Cabang Rantauprapat sudah masuk kategori baik. 
Hasil penelitian menunjukkan adanya hubungan yang kuat antara sistem informasi manajemen dengan kinerja karyawan pada PT.BRI cabang Rantauprpat. Nilai R diperoleh sebesar 0.750. Hal ini berarti nilai R terdapat antara 1 dan -, dengan demikian dapat dinyatakan bahwa sistem informai manajemen memiliki hubungan dengan kinerja karyawan. Nilai $\mathrm{R}$ sebesar 0.750 menunjukkan bahwa sistem informasi manajemen memiliki hubugan yang kuat terhadap kinerja karyawan BRI Cabang Rantaprapat. Nilai R2 (R square) sebesar 0.5625 memberi makna bahwa pengaruh variabel yang diuji memiliki pengaruh sebesar $56,25 \%$ terhadap kinerja karyawan BRI Cabang Rantauprapt, sedangkan 43,75\% dipengaruhi oleh variabel lain yang tidak diteliti dalam penelitian ini.Sistem informasi manajemen memiliki peranan penting dalam mencapai tujuan perusahaan. Perusahaan yang memiliki sistem informasi manajemen yang bagus akan memberikan hasil yang bagus pula.

Hasil penelitian ini sejalan dengan penelitian yang dilakukan oleh Rizan Machmud (2013) yang menyimpulkan bahwa Hasil penelitian menunjukkan bahwa terdapat hubungan yang positif dan signifikan antara sistem informasi manajemen dengan kinerja pegawai pada Rumah Tahanan (Rutan) di Makassar. Hal ini dibuktikan dari hasil analisis korelasi sederhana diperoleh koefisien korelasi (rx1y) sebesar 0,214 dan rtabel dengan $\mathrm{N}=60$ pada taraf signifikansi $5 \%$ sebesar 1,671. Hal ini menunjukkan bahwa rhitung positif dan lebih besar dari rtabel $(0,214>1,671)$.

Dari penjelasan di atas dapat disimpulkan bahwa variabel sistem informasi manajemen dengan kinerja pegawai pada Rumah Tahanan (Rutan) di Makassar mempunyai hubungan postif dan signifikan.

Hasil penelitian ini juga diperkuat dengan artikel oleh Basrowi (2015) yang menyatakan Bila SIM dihubungkan dengan kinerja SDM perusahaan maka dapat dipahami bahwa semakin baik SIM semakin tinggi pula kinerja SDM yang disuguhkan kepada perusahaan, betapa tidak, karena dengan SIM yang baik, tidak ada lagi kesulitan bagi SDM untuk mendapatkan data valid yang dibutuhkan, sehingga memudahkan dalam membuat keputusan yang tepat dalam memecahkan permasalahan yang dihadapi oleh setiap SDM. Selain itu, dengan SIM yang bagus, seluruh data telah terhubung ke seluruh unit kerja sehingga mempercepat proses penyelesaikan pekerjaan yang berkaitan dengan data keuangan, kepegawaian, produksi, distribusi, pemasaran, profit, asset, pajak, segala kewajiban perusahaan dan data penting lainnya sehingga akan sangat memudahkan bagi SDM untuk berkinerja prima, dan mudah dalam memberikan pelayanan prima kepada stakeholders perusahaan/organisasi. Dengan demikian, semakin baik kualitas sistem informasi manajemen semakin baik pula kinerja sumber daya manusia. Sebaliknya, semakin rendah kualitas sistem informasi manajemen semakin rendah pula kinerja sumber dayamanusia.

Hasil penelitian ini juga diperkua dengan hasil penelitian oleh Johan Fadrin (2008), berdasarkan penelitian sarana Sistem Informasi Manajemen (SIM) yang dimiliki PT Golden Gate Mandiri sampai saat ini untuk mempermudah kebutuhan akan pengolahan data sampai membantu manajer dalam proses pengambilan keputusan bagi perusahaan, diantaranya DNS \& Mail Server, DB \& Web Server, PC Router, Firewall \& Proxy, koneksi ke internet menggunakan Speedy dengan banwidth $512 \mathrm{Kbps}$, dan menggunakan D-Link ADSL Router 1 port, infrastruktur jaringan lokal mempergunakan kabel UTP 100 Base-TX, Belden CAT.5, HUB terdiri dari One Level 16 port, dan tiga Hub D-Link 8 port, dan sekitar dua puluh komputer clien yang digunakan karyawan yang menggunakan sistem operasi Windows XP Sp 2, scanner Canon Ldi, printer Epson Lq 2180, Lq- 300, Canon Pixma, Hp deskjet, software PPS-AD untuk membuat dokumen pabean, software Modul Pengangkut untuk keperluan pengolahan manifest. 
Berdasarkan perhitungan, diperoleh nilai analisis korelasi Rank Spearman sebesar 0,73. Ini berarti antara Sistem Informasi Manajemen (SIM) berbasis komputer dengan Kinerja Karyawan mempunyai hubungan yang cukup kuat atau tinggi. Dari hasil perhitungan menggunakan koefisien determinasi diperoleh kd sebesar 53,29\%. Ini berarti kinerja karyawan PT Golden Gate Mandiri yang dipengaruhi oleh Sistem Informasi Manajemen (SIM) berbasis komputer pada perusahaan (PT GGM) adalah sebesar 53,29\%. Sedangkan sisanya sebesar $46,71 \%$ dipengaruhi oleh faktor lain yang tidak diukur. Hasil ini telah diuji signifikan atau kecocokan dengan menggunakan uji t satu sisi, dimana diperoleh $\mathrm{t}$ (hitung) 4,533 lebih besar dari $\mathrm{t}$ (tabel) 2,552 pada tingkat signifikan 1\%. Hal ini berarti hipotesis yang penulis ajukan, yaitu â Apabila perusahaan dapat menerapkan Sistem Informasi Manajemen berbasis komputer yang tepat maka kinerja karyawan akan meningkat.â dapat diterima.

Kesimpulan

Hasil penelitian dalam penelitian ini adalah terbukti bahwa slstem informasi manajemen memiliki hubungan yang kuat dengan kinerja karyawan PT. BRI Cabang Rantauprapat. Artinya apabila penerapan system informasi manajemen dilkakukan dengan baik, maka kinerja juga akan semakin meningkat.

\section{Saran}

Informasi merupakan salah satu aset penting dalam dunia bisnis, oleh karena BRI sebagai perusahaan besar harus terus berupaya meningkatkan kualitas system informasi manajemen untuk mendukung kinerja karyawan .

\section{Daftar Pustaka}

Azhar Susanto. 2013. Sistem Informasi Akuntansi. Bandung: Lingga Jaya.

Basrowi (2015) Hubungan Sim Dengan Sdm, Tenaga, Kinerja, Perkantoran Modern Dan Data Base. $\quad$ Http://Opinisosiologipendidikan.Blogspot.Co.Id/2015/03/Hubungan-Sim Dengan-Sdm-Tenaga-Kinerja.Html. Diakses Pada Hari Senin, Tanggal 4 Januari 2016.

Anwar Prabu Mangkunegara, 2007, Manajemen Sumber Daya Manusia,. Cetakan Ke Tujuh PT. Remaja Rosdakarya, Bandung.

Jogiyanto. 2000. Pengenalan Komputer : Dasar Ilmu Komputer,. Pemograman, Sistem Informasi, dan Intelegensi Buatan.

Rizan (2013). Hubungan Sistem Informasi Manajemen Dan Pelayanan Dengan Kinerja Pegawai Pada Rutan Makassar Vol. 9 No. 1 Maret 2013 (Jurnal Capacity Stie Amkop Makassar) Issn : 1907-3313 